\title{
Trade flows and trade specialisation: The case of China ${ }^{\text {is }}$
}

\author{
Guglielmo Maria CAPORALE ${ }^{\mathrm{a}, *}$, Anamaria SOVA $^{\mathrm{b}}$, Robert SOVA ${ }^{\mathrm{c}}$ \\ a Brunel University London, CESifo and DIW Berlin \\ b EBRC, Romania \\ c Bucharest University of Economic Studies, Romania
}

\section{A R T I C L E I N F O}

\section{Article history:}

Received 10 July 2014

Received in revised form 16 March 2015

Accepted 16 March 2015

Available online 2 April 2015

\section{JEL classification:}

C23

F14

F15

Keywords:

Gravity model

Panel data analysis

Trade specialisation

Comparative advantage
A B S T R A C T
Using annual data for the periods 1992-2012, this paper examines trade flows between China and
its main trade partners in Asia, North America and Europe, and whether increasing trade has led to
industrial structural adjustment and changes in China's trade patterns. The analysis is based on
both economic indicators and the estimation of a gravity model, and applies recently developed
panel data methods that explicitly take into account unobserved heterogeneity, specifically the
fixed effect vector decomposition (FEVD) technique. The findings confirm the significant change
in China's trading structure associated with the fast growth of foreign trade. In particular, there
has been a shift from resource- and labour-intensive to capital- and technology-intensive exports.
c 2015 The Authors. Published by Elsevier Inc. This is an open access article under the CC BY license

(http://creativecommons.org/licenses/by/4.0/).

\section{Introduction}

Since the reform process started and an opening-up policy was adopted, China has experienced a sharp increase in its growth rate and also its trade with the rest of the world: it has successfully converted itself from a country with protectionist trade policies to an outward-oriented one with an open economy. During this transition its trade relations with the rest of the world went through various stages, from isolation and dependence on the Soviet economy to openness. Its accession to the World Trade Organization (WTO) was a key step giving China the opportunity to participate in world trade within a multilateral trade system.

China's integration into the global economy has been one of the main drivers of its economic growth. A particularly important contribution to GDP and employment growth has been made by some of its industries with comparative advantages and an increasing specialisation level. China has pursued in recent years export-oriented economic policies and becomes a big trader in world markets and the biggest economy after the US and Japan. International trade has also helped improve the productivity of some domestic industries and led to faster technological progress. In particular, large imports of capital and intermediate goods have had an important effect on productivity through the technology incorporated in them; "learning by doing" has also played a key role. An increase in trade of machinery parts and components (both exports and imports) and the convergence of the commodity composition of exports and imports have made intra-industry trade more important than before in East Asia (Ando, 2006).

The last decades have seen a further, sharp rise in trade flows between China and the rest of the world, the European Union (EU), the US, Japan and other OECD economies becoming major trade partners for China. Its competitiveness mainly reflects low labour costs: despite the fast economic growth of the past three decades manufacturing wages are still low in China compared to the

\footnotetext{
is We are grateful to two anonymous referees for their useful comments.

* Corresponding author at: Department of Economics and Finance, Brunel University London, UB3 8PH, UK.

E-mail address: Guglielmo-Maria.Caporale@brunel.ac.uk (G.M. Caporale).
} 
OECD and most East Asian countries (Adams, Gangnes, \& Shachmurove, 2006). Foreign direct investment (FDI) inflows combining low labour costs and foreign technology have also improved the efficiency of Chinese industries. This has resulted in inter-industry spillovers to China's manufacturing sector (Wei \& Liu, 2006), and in technology and management skill flows (Adams et al., 2006).

However, the global financial crisis of 2007-8 affected the main Chinese export markets (EU, US, and Japan) and both export growth and FDI have decreased over the last few years, although less than in the US and the European countries most hit by the crisis.

The present study analyses trade flows between China and its main trade partners in Asia, North America and Europe. In particular, it examines whether increasing trade has also led to industrial structural adjustment and changes in China's trade patterns. The analysis is based on both economic indicators and the econometric estimation of a gravity model, which is suitable for both intra- and inter-industry trade. It uses developed panel data methods that explicitly take into account unobserved heterogeneity, i.e. the fixed effect vector decomposition (FEVD) technique proposed by Plumper and Troeger (2007).

The paper is organised as follows. Section 2 provides some information on the evolution of China's trade flows with its main partners. Section 3 outlines the gravity model which is the theoretical framework underlying the empirical analysis. Section 4 discusses the econometric model and the empirical results. Section 5 offers some concluding remarks.

\section{The evolution of China's international trade}

Before 1978, China was a centrally planned economy with minimal trade with the rest of the world and low export and import rates, its exports being only some manufactured goods and raw materials sold to be able to import goods not produced domestically. The adopted protectionist and import substitution policies were aimed at improving China's export structure and fostering the growth of the domestic industry and of the economy as a whole. International trade normally facilitates capital accumulation, optimal resource allocation, technological progress and productivity improvements. However, in the case of China both the static and dynamic gains from free trade were limited, owing to the lack of competition.

From 1978, China has pursued trade liberalisation in addition to making other significant changes to its economic structure with the aim of establishing a socialist market economy. However, this has been a gradual process. Sustained economic growth and the resulting increase in average income initially led to a sharp rise in imports. At the beginning of the 1980s, tariffs were imposed on many products to stop the inflow of foreign products into the Chinese market. To encourage the market mechanism and a more effective resource allocation the Chinese government cancelled its import substitution list in the 1980s, and gradually reduced import and export restrictions in the form of both tariffs and non-tariff barriers. Following the adoption of liberalisation policies, foreign investors were able to set up joint ventures and import new technology into China: FDI had an important role in the transfer of technology and of management skills.

In 2001, China joined WTO. To meet the membership requirements, it had to modify and improve its administrative regulations and laws, in particular those concerning foreign trade and economic cooperation (Cross, 2004), such as the Trademark Law, and the Law on Joint Ventures with Chinese and Foreign Investment. Other legislation not in compliance with WTO requirements was revised or abolished. China's WTO membership has strengthened and improved the multilateral trading system, and promoted world economic and trade development. Furthermore, it has contributed to reducing the technological gap between China and the developed countries. After becoming a WTO member, China continued to reduce trade restrictions: in 2004 it lowered its average tariff rate to $10.7 \%$; by 2012, it was below 9\%; non-tariff barriers such as licenses, import quotas, trading practices etc. have also been gradually removed. The dismantling of trade barriers led to a restructuring of the industries that previously had strong government protection (such as the automobile, chemical and electronics ones - Greeven (2004)).

The steady expansion of China's international trade since its opening up shows how a latecomer can create a place for itself in the international markets. Trade volumes have grown in the last 21 years at an average annual rate of $18.1 \%$ for exports and $17.7 \%$ for imports (see Table A1). Over this period, the trade balance has normally been in surplus (see Fig. A5). China's share in global trade and its global ranking have gone up steadily: in 2012 its trade volume accounted for $11.3 \%$ of global trade (see Table A2), outperforming other emerging countries. The structural reforms of recent years have significantly improved its competitiveness and trade performance: the share of primary goods in total exports was initially higher than that of manufactured goods, but has been declining over time and has been overtaken by the latter. China's main trading partners since its foreign trade was liberalised have been the OECD economies, accounting for $49.7 \%$ of total trade in 2012. China's top eighteen (18) trading partners in 2012 in terms of trade volume and share are shown in Table A3. Trade with these countries accounted for $62.4 \%$ of total trade in 2012 . The main trading partner in 2012 was the EU (14.1\%), followed by the US (12.6\%) (see Tables A2 and A3). Trade with the rest of the world has increased by a factor of 23 since 1992 (see Table A1) and even more, by a factor of 25, with the EU and US (see Fig. A6). However, trade with emerging economies is also becoming important, with China looking for new potential markets for its products.

A few previous studies have investigated trade between China and the rest of the world. In particular, Yang and Martinez-Zarzozo (2014) examined trade creation and diversion effects of the free trade agreements between China and ASEAN using a sample of 31 countries over the period from 1995 to 2010 . They used aggregate and disaggregate export data for agricultural and manufactured goods (chemical products, machinery and transport equipment). They found that these free trade agreements (ACFTA) led to significant trade creation. Lee, Park, and Wang (2013) analysed China's imports, estimating the relative importance of the extensive margin (number of goods) versus the intensive margin (the amount traded per good), and examining the role of both firm heterogeneity and product heterogeneity, shedding some light on China's trade patterns following its recent emergence as a globally significant importer. BahmaniOskooee and Ratha (2010) tested the S-Curve using bilateral trade data between the US and China. They reported that there is no evidence of an S-Curve at the aggregate level; however, disaggregate data by commodity (two and three digit SITC classifications) indicate the existence of such a curve in almost $50 \%$ of the cases in a sample of almost 100 industries. 
Xing and Whalley (2014) used a database on the commodity transactions of firms to analyse internal trade in China. They found a positive relationship with international trade in most cases, which suggests complementarity between the two. Internal trade in China has grown quickly but with seasonal fluctuations, and it remains smaller than inter-state trade in the US and intra-EU trade. Marelli and Signorelli (2011) analysed the integration of China and India into the global economy and the effects of trade on their economic growth. They highlighted the fact that China has gone beyond the initial industrialisation stage (specialisation in traditional manufacturing) and is increasingly specialising in more innovative sectors such as telecommunications and office equipment. ${ }^{1}$

Our main focus is on the evolution of trade patterns for China since its opening up. In particular, we examine whether increasing trade flows have led to industrial structural adjustment. As can be seen from Figs. A1 and A3 and Table A6, Chinese exports of machinery, transport equipment increased sharply between 1992 and 2012: whilst the labour-intensive sectors dominated in the early years of the period being analysed, the capital intensive ones have become much more important in recent years. Initially, 39.85\% of exports was represented by miscellaneous manufactured articles, $19 \%$ by basic manufactures, $16 \%$ by machinery and transport equipment and $5 \%$ by chemicals and related products; therefore, exports of labour-intensive sectors, with the comparative advantage of low labour costs, dominated. However, the relative importance of capital-intensive industries has increased over time: the three main export sectors in 2012 were machinery and transport equipment (47.12\%), miscellaneous manufactured articles (26.05\%), and basic manufactures (16.31\%). The percentages for sectors such as basic manufactures and miscellaneous manufactured articles have instead declined since 1992 (from $19 \%$ to $16.31 \%$, and from $39.85 \%$ to $26.05 \%$ respectively). As for imports, in addition to capital-intensive products (35.94\%), China is also importing mineral fuels (17.22\%) and crude materials (14.83\%) necessary for the development of its domestic industries (see Figs. A2 and A4).

The analysis of sectoral trade adjustment is based on revealed comparative advantage calculations. We use the indicator developed by Lafay (1990), which measures the relative contribution of product $\mathrm{k}$ to the overall trade balance, a positive (negative) sign indicating the existence of a comparative advantage (disadvantage). Table A4 shows the evolution of trade patterns over the years. The comparative advantage for China vis-à-vis its main trade partners still concerns labour-intensive products, in particular miscellaneous manufactured articles (apparel and clothing accessories, footwear, and furniture), but has been declining over time. Generally, capital-intensive sectors have a comparative disadvantage. An example is the machinery, transport equipment sector, although its exports have increased (and the disadvantage decreased) over time. However, most recently China has also developed a comparative advantage in capital-intensive sectors such as office machines (75), telecommunications and sound recording equipment (76), and electric machinery (77) vis-à-vis the EU. The main comparative disadvantage occurs for road vehicles (78).

The other index calculated for the analysis of trade patterns is the Grubel and Lloyd (1975) one, which is widely used to measure intra-industry trade. According to classical theory, inter-industry trade (IT) implies export and import flows of complementary products, whilst intra-industry trade (IIT) is characterised by simultaneous export and import flows of comparable size within the same industry. The GL index indicates that intra-industry trade dominates when it is close to 1. A high share of intra-industry trade suggests a high level of industrial development, and can have significant long-term benefits. The results are reported in Table A5. There appears to be an increase in the GL index during the period under investigation, which indicates a growing importance of intra-industry trade. In 1992, inter-industry trade was dominant, but by 2012 the relative importance of intra-industry trade had increased. However, the index by itself does not allow us to distinguish between vertical and horizontal intra-industry trade.

Overall, the above analysis suggests that China's entry into the global market and the rapid growth of the volume of its foreign trade have led to significant changes in trade patterns, namely a shift in the composition of exports from labour-intensive products to capital- and technology-intensive goods, i.e. from light industry in the early years of the sample to machinery and electronic goods with high technology in recent years. Next, we outline the gravity model which is the theoretical framework underlying the subsequent panel data analysis aimed at shedding more light on the determinants of trade between China and its main partners as well as its changing patterns.

\section{The gravity model}

The gravity model is widely used as a benchmark to estimate trade flows between countries. ${ }^{2}$ Trade flows from country $i$ to country $j$ are modelled as a function of the supply of the exporter country, the demand of the importer country and trade barriers. In other words, national incomes of two countries, transport costs (transaction costs) and regional agreements are assumed to be the main determinants of trade. Initially inspired by Newton's gravity law, gravity models have become essential tools in the analysis of international trade flows. The first applications were rather intuitive, without theoretical foundations. They included the contributions of Tinbergen (1962) and Pöyhönen (1963). Subsequently, the new international trade theory provided theoretical justifications for these models in terms of increasing returns of scale, imperfect competition and geography (transport costs) (see Anderson (1979); Bergstrand (1985); Helpman \& Krugman (1985)).

Linnemann (1966) proposed a gravity model based on a Walrasian, general equilibrium approach. He explained exports of country $i$ to country $j$ in terms of the interaction of three factors: potential supply of exports of country $i$, potential demand of imports from country $j$, and trade barriers. The first variable is a positive function of the exporting country's income level and can also be interpreted

\footnotetext{
1 Ando (2006) studied the developments in trade structure and vertical international production sharing in East Asia in the 1990s. He found an increase in the importance of vertical intra-industry trade (IIT) increased reflecting the expansion of back-and-forth transactions in vertically fragmented cross-border production processes. Vertical international production sharing became a key feature of the East Asian economies in the 1990s. A more general study by Arora and Vamvakidis (2004) analysed the effects of trade on economic growth for a large sample of countries. Their panel estimation results suggest that industrial countries benefit from trading with developing countries growing rapidly, whilst emerging economies gain from trading with developed countries with relatively high income and technology.

2 Eichengreen and Irwin (1995) consider it "the workhorse for empirical studies of regional integration".
} 
as a proxy for product variety. The second is a positive function of the importing country's income level. The third is a negative function of trade costs, transport costs, and tariffs.

Bergstrand (1989) also included per capita income, which is an indicator of demand sophistication (demand for luxury versus necessity goods), and incorporated factor endowment variables (Heckscher-Ohlin) and taste variables (Linder) in the following specification:

$$
P X_{i j}=\Psi_{0}\left(Y_{i}\right)^{\Psi_{1}}\left(Y_{i} / L_{i}\right)^{\Psi_{2}}\left(Y_{j}\right)^{\Psi_{3}}\left(Y_{j} / L_{L_{j}}\right)^{\Psi_{4}}\left(D_{i j}\right)^{\Psi_{5}}\left(A_{i j}\right)^{\Psi_{6}} e_{i j}
$$

where $P X_{i j}$ represents flows from country $i$ to country $j, \Psi_{0}$ is the intercept, $Y_{i}$ and $Y_{j}$ are the GDP of countries $i$ and $j$ respectively, $\left(Y_{i} / L_{i}\right)$ and $\left(Y_{j} / L_{j}\right)$ stand for GDP per capita of countries $i$ and $j$ respectively, $D_{i j}$ represents the geographical distance between the economic centres of two partners, and $A_{i j}$ factors aiding (e.g., common language and historical bonds) or representing a barrier to trade between partners.

Helpman (1987) used a model of trade in differentiated products to estimate the share of intra-industry trade (Grubel-Lloyd index for four-digit SITC groups) for separate cross-sections of country pairs for the period 1970-1981. He found that the share of intraindustry trade is negatively correlated with income differences and positively correlated with country size. Also, the more similar factor endowments are, the larger the share of intra-industry trade is. Several other studies (Evenett \& Keller, 2002; Hummels \& Levinsohn, 1995) have reported similar results.

The gravity model has also been widely used in the applied literature to evaluate the impact of regional agreements (see Carrere (2006); Frankel (1997)), the border effect on trade flows (Anderson \& Van Wincoop, 2003), and trade potential (Baldwin, 1994; Péridy, 2005).

\section{Econometric analysis}

\subsection{Econometric issues}

The gravity model is the theoretical underpinning of the econometric framework we adopt. As heterogeneity plays an important role in bilateral flows, individual fixed effects are introduced into the empirical model to take it into account. The evolution over time of countries' behaviour can also be examined through temporal fixed effects (for economic or political events).

Most studies estimating a gravity model apply the ordinary least square (OLS) method to cross-section data. However, several papers have argued that standard cross-section methods lead to biased results because they do not take into account heterogeneity (e.g., historical, cultural and linguistic factors). For example, Matyas (1997) stresses that the cross-section approach is affected by misspecification and suggests that the gravity model should be specified as a "three-way model" with exporter, importer and time effects (random or fixed ones). Panel data methods are therefore preferable as they enable one to control for specific effects (such as fixed or random effects), and hence eliminate the potential endogeneity bias resulting from unobserved individual heterogeneity. Egger and Pfaffermayr (2003) underline that the omission of specific effects for country pairs can bias the estimated coefficients. An alternative solution is to use an estimator to control bilateral specific effects as in a fixed effect model (FEM) or in a random effect model (REM). The advantage of the former is that it allows for unobserved or misspecified factors that explain simultaneously the trade volume between two countries and lead to unbiased and efficient results.

Plumper and Troeger (2007) have proposed a more efficient method called "the fixed effect vector decomposition (FEVD)" to accommodate time-invariant variables. Using Monte Carlo simulations, they compared the performance of the FEVD method to some other existing techniques, such as the fixed effect, or random effect, or the Hausman-Taylor methods. Their results indicate that the most reliable technique for small samples is FEVD if time-invariant variables are present and the other variables are correlated with specific effects, which is likely in our case. Therefore the FEVD approach will be taken in this study.

\subsection{Model specification}

Our aim is to analyse the determinants of trade between China and its main partners as well as of trade specialisation by estimating a gravity model. Following trade theory, we estimate a trade equation where difference in relative factor endowments $\left(D G D P T_{i j}\right)$ is the main determinants of specialisation. The bigger the difference between the partners' factor endowments, the higher the share of interindustry trade will be. Helpman (1987) in fact found a negative correlation between the share of intra-industry trade and differences in relative factor endowments.

We model bilateral exports as a function of GDP, the difference in per capita income, geographical distance, FDI inflows and the dummy variables defined below. The total trade of each country is given by the sum of inter- and intra-industry trade volumes.

The estimated equation is the following:

$$
X_{i j t}=e^{a_{0}} G D P_{i t}^{a_{1}} G D P_{j t}^{a_{2}} D G D P T_{i j t}^{a_{3}} D I S T_{i j}^{a_{4}} L L K_{i}^{a_{5}} W T O_{i j t}^{a_{6}} C R S_{t}^{a_{7}} F D I_{i t}^{a_{8}} e^{u_{i j}} e^{\eta_{t}} e^{\varepsilon_{i j t}}
$$

where:

- $X_{i j t}$ denotes total trade between countries $i$ and $j$ at time $t$ with $i \# j$ (source: COMTRADE);

- $a_{0}$ is the intercept;

- $G D P_{i t}$ stands for Gross Domestic Product of country $i$, source: IMF;

- $G D P_{j t}$ stands for Gross Domestic Product of country $j$, source IMF; 
Table 1

Bilateral trade between China and the rest of the world.

\begin{tabular}{|c|c|c|c|}
\hline \multirow[t]{2}{*}{ Variables } & $1992 \rightarrow 2012$ & $1992 \rightarrow 2001$ & $2002 \rightarrow 2012$ \\
\hline & $X_{i j t}$ & $X_{i j t}$ & $X_{i j t}$ \\
\hline$G D P_{i t}$ & $\begin{array}{l}1.209 \\
(24.37)^{\text {*** }}\end{array}$ & $\begin{array}{l}0.752 \\
(13.87)^{\text {*** }}\end{array}$ & $\begin{array}{l}1.241 \\
(21.52)^{\text {*** }}\end{array}$ \\
\hline$G D P_{j t}$ & $\begin{array}{l}0.803 \\
(18.79)^{* * *}\end{array}$ & $\begin{array}{l}0.778 \\
(14.32)^{\text {*** }}\end{array}$ & $\begin{array}{l}0.983 \\
(16.29)^{* * *}\end{array}$ \\
\hline$D G D P T_{i j t}$ & $\begin{array}{l}-0.084 \\
(4.16)^{* * *}\end{array}$ & $\begin{array}{l}0.179 \\
(7.02)^{* * *}\end{array}$ & $\begin{array}{l}-0.025 \\
(2.07)^{* *}\end{array}$ \\
\hline$D_{I S T} T_{i j}$ & $\begin{array}{l}-1.273 \\
(29.14)^{\text {*** }}\end{array}$ & $\begin{array}{l}-1.860 \\
(19.26)^{\text {*** }}\end{array}$ & $\begin{array}{l}-0.810 \\
(32.41)^{\text {*** }}\end{array}$ \\
\hline$L L K_{i j}$ & $\begin{array}{l}-0.303 \\
(12.09)^{\text {*** }}\end{array}$ & $\begin{array}{l}-0.545 \\
(14.14)^{\text {*** }}\end{array}$ & $\begin{array}{l}-0.187 \\
(4.17)^{* * *}\end{array}$ \\
\hline$W T O_{i j t}$ & $\begin{array}{l}0.048 \\
(1.79)^{*}\end{array}$ & $\begin{array}{l}- \\
-\end{array}$ & $\begin{array}{l}0.052 \\
(2.13)^{* *}\end{array}$ \\
\hline$F D I_{i t}$ & $\begin{array}{l}0.241 \\
(8.70)^{* * *}\end{array}$ & $\begin{array}{l}0.094 \\
(2.23)^{* *}\end{array}$ & $\begin{array}{l}0.303 \\
(14.17)^{* * *}\end{array}$ \\
\hline$C R S_{t}$ & $\begin{array}{l}-0.027 \\
(1.67)^{*}\end{array}$ & $\begin{array}{l}- \\
-\end{array}$ & $\begin{array}{l}-0.070 \\
(1.78)^{*}\end{array}$ \\
\hline Constant & $\begin{array}{l}3.188 \\
(29.33)^{\text {**** }}\end{array}$ & $\begin{array}{l}7.142 \\
(47.10)^{\text {*** }}\end{array}$ & $\begin{array}{l}1.324 \\
(10.67)^{* * *}\end{array}$ \\
\hline Observations & 7980 & 3800 & 4180 \\
\hline R-squared & 0.89 & 0.91 & 0.94 \\
\hline
\end{tabular}

t statistics in parentheses.

Note: t-values are reported below each coefficient. Data sources: $X_{i j t}$ denotes total trade between countries $i$ and $j$ (millions USD - source: COMTRADE database); GDP ${ }_{i t}$, $G D P_{j t}$ stand for Gross Domestic Product of country $i$ and country $j$ (millions USD - source: International Monetary Fund (IMF) database); $D G D P T_{i j t}$ is the difference in Gross Domestic Product per capita between partners and is a proxy for economic distance or comparative advantage intensity (USD - source: IMF; authors' calculations); $W_{T O}$ is a dummy variable that equals 1 if country $i$ joined the World Trade Organization (WTO), and zero otherwise (source: WTO); DIST $_{i j}$ represents geographical distance between the capitals of country $i$ and country $j$ respectively (kilometres - source: CEPI database (Centre d'Etudes Prospectives et d'Informations Internationales)); $L L K_{i j}$ is a dummy variable that is equal to 1 if countries $i$ and $j$ are landlocked, and zero otherwise (source: CEPI database); FDI ${ }_{i t}$ represents FDI inflows into China in year $t$ (millions USD - source: UNCTAD database); $C R S_{t}$ is a dummy variable for the global economic crisis - equal to 1 starting from year 2007 and 0 otherwise.

* Significant at $10 \%$

** Significant at $5 \%$.

*** Significant at $1 \%$.

- $D G D P T_{i j t}$ is the difference in GDP per capita between partners and is a proxy for economic distance or comparative advantage intensity, source: authors' calculations;

- DIST $_{i j}$ represents geographical distance between the capitals of country $i$ and country $j$ respectively, source: CEPII;

- $L L K_{i j}$ is a dummy variable that is equal to 1 if countries $i$ and $j$ are landlocked, and zero otherwise, source: CEPII;

- $W T O_{i t}$ is a dummy variable that equals 1 if country $i$ joined the WTO, and zero otherwise;

- $F D I_{i t}$ represents FDI inflows into China in year t, source: UNCTAD;

- $C R S_{t}$ is a dummy variable for the global economic crisis equal to 1 for 2007-2008 and to 0 otherwise;

- $u_{i j}$ is country-pair fixed effects;

- $\eta_{t}$ is time effects;

- $\varepsilon_{i j t}$ is the error term.

After log-linearisation, Eq. (2) becomes the following in a static context:

$$
\begin{aligned}
\log \left(X_{i j t}\right)= & a_{0}+a_{1} \log \left(G D P_{i t}\right)+a_{2} \log \left(G D P_{j t}\right)+a_{3} \log \left(D G D P T_{i j t}\right)+a_{5} \log \left(D I S T_{i j}\right)+ \\
& +a_{6} L L K_{i j}+a_{7} W T O_{i j t}+a_{8} \log \left(F D I_{j t}\right)+a_{9} C R S_{t}+u_{i j}+\eta_{t}+\varepsilon_{i j t}
\end{aligned}
$$

The data are annual and cover a period of 21 years (1992-2012). As indicated above, the data sources are COMTRADE, IMF, CEPII, UNCTAD. ${ }^{3}$ We proceed in three stages. First, we analyse trade between China and the rest of the world (190 countries), then focus on a subset, i.e. its main trading partners ( 18 developed countries). ${ }^{4}$ Finally, we analyse trade between China and the EU, which has become China's main trade partner. The model is estimated over the whole sample, and then over two subsamples (1992-2001 and 2002-2012) in order to detect any changes in trade specialisation for China vis-à-vis its partners.

The expected sign for the effect of country size (measured by GDP) on bilateral exports is positive. Also, export supply and import demand should be a positive function of the income of the trade partners. The sign of the coefficient on difference in GDP per capita, which is a measure of the difference in factor endowments between countries, should be positive as well according to the Heckscher-

\footnotetext{
${ }^{3}$ COMTRADE - International Trade Statistics Database; IMF - International Monetary Fund; CEPII - Centre d'Etudes Prospectives et d'Informations Internationales; UNCTAD - United Nations Conference on Trade and Development.

${ }^{4}$ US, Japan, Hong Kong, South Korea, Taiwan, Germany, Australia, Singapore, Netherlands, Indonesia, United Kingdom, France, Italy, Canada, Malaysia, Russian Federation, India, Thailand - countries whose annual average trade is higher than 2 billion USD.
} 
Ohlin hypothesis - the greater this difference, the greater the relative importance of inter-industry trade will be. On the contrary, new trade theory would imply a negative coefficient. Geographical distance is a proxy for transport costs, tariff and non-tariff barriers and should have a negative coefficient. WTO membership instead is expected to have a positive sign. Finally, the sign of the coefficient on the financial crisis dummy is expected to be negative given the available evidence of a decline in Chinese trade over that period.

\subsection{Results}

The estimation results using FEVD are reported in Tables 1 to 3. For the static panel data analysis, FEVD is the most appropriate method given our sample size, and produces a high $\mathrm{R}^{2}$ ( 0.88 - see Tables 1 to 3$)$. The advantage of this method is that it also highlights the effects of time-invariant variables on trade flows. Fixed effects are included to account for country-specific effects as well as other factors not already considered that might affect trade.

It can be seen that the coefficients are significant in almost all cases and their signs are consistent with theory. The country size of China and its trade partners are important factors determining trade flows. Geographical distance is negatively related to trade volumes as expected. WTO membership has a positive impact on trade. There is also a positive effect of FDI on trade between China and the rest of the world. This may reflect the needs of the Chinese subsidiaries of multinationals to import intermediate goods and equipment, which suggests that there is trade at firm level. Also, FDI inflows take place mainly for the industries and sectors with a comparative advantage reflecting lower labour costs, further improving productivity and increasing exports. The financial crisis had a negative effect on trade, especially exports. The subsample analysis highlights a shift towards trade in capital goods in the second period, possibly resulting from a production fragmentation strategy pursued by multinationals.

The descriptive statistics show that almost 60\% of trade during the periods $2000-2012$ took place with the main partners, these being developed countries. It is interesting to analyse trade and specialisation patterns (see Table 2). Bilateral exports are affected positively by country size, WTO membership and FDI. On the contrary, the distance variable (a proxy for transportation costs) and the financial crisis have a negative effect. The main determinant of trade patterns is the difference in GDP per capita. As before, in the second subsample a shift towards capital-intensive goods can be observed. The descriptive analysis also shows an increase in trade for the mechanical and electrical equipment sectors. This may reflect a higher number of back-and-forth transactions as the production process becomes more fragmented: imports of intermediate goods and equipment are used by local subsidiaries to produce goods to be exported. Over the period examined there was a sizeable increase in imports of intermediate goods, especially after 2000. Besides, since then the presence of multinationals in China has increased considerably, and fast economic growth has been experienced.

The results for trade between China and the EU, currently its main trade partner, are reported in Table 3.

Table 2

Bilateral trade between China and its main trading partners.

\begin{tabular}{|c|c|c|c|}
\hline \multirow[t]{2}{*}{ Variables } & $1992 \rightarrow 2002$ & $1992 \rightarrow 2001$ & $2002 \rightarrow 2002$ \\
\hline & $X_{i j t}$ & $X_{i j t}$ & $X_{i j t}$ \\
\hline$G D P_{i t}$ & $\begin{array}{l}1.210 \\
(12.58)^{* * *}\end{array}$ & $\begin{array}{l}1.150 \\
(9.38)^{* * *}\end{array}$ & $\begin{array}{l}0.855 \\
(28.18)^{* * *}\end{array}$ \\
\hline$G D P_{j t}$ & $\begin{array}{l}1.027 \\
(10.62)^{* * *}\end{array}$ & $\begin{array}{l}1.284 \\
(10.55)^{* * *}\end{array}$ & $\begin{array}{l}0.715 \\
(23.49)^{* * *}\end{array}$ \\
\hline$D G D P T_{i j t}$ & $\begin{array}{l}-0.350 \\
(2.15)^{* *}\end{array}$ & $\begin{array}{l}0.521 \\
(7.21)^{* * *}\end{array}$ & $\begin{array}{l}-0.046 \\
(1.77)^{*}\end{array}$ \\
\hline$D_{I S T} T_{i j}$ & $\begin{array}{l}-1.499 \\
(33.51)^{* * *}\end{array}$ & $\begin{array}{l}-1.902 \\
(41.57)^{* * *}\end{array}$ & $\begin{array}{l}-0.883 \\
(48.10)^{* * *}\end{array}$ \\
\hline$L L K_{i j}$ & $\begin{array}{l}-0.393 \\
(8.16)^{* * *}\end{array}$ & $\begin{array}{l}-0.101 \\
(1.22)\end{array}$ & $\begin{array}{l}-1.206 \\
(21.91)^{* * *}\end{array}$ \\
\hline$W T O_{i j t}$ & $\begin{array}{l}0.039 \\
(1.68)^{*}\end{array}$ & & $\begin{array}{l}0.041 \\
(1.89)^{*}\end{array}$ \\
\hline$F D I_{i t}$ & $\begin{array}{l}0.260 \\
(5.75)^{* * *}\end{array}$ & $\begin{array}{l}0.085 \\
(2.23)^{* *}\end{array}$ & $\begin{array}{l}0.195 \\
(6.19)^{* * *}\end{array}$ \\
\hline$C R S_{t}$ & $\begin{array}{l}-0.070 \\
(2.32)^{* *}\end{array}$ & - & $\begin{array}{l}-0.095 \\
(2.14)^{* *}\end{array}$ \\
\hline Constant & $\begin{array}{l}5.737 \\
(33.81)^{* * *}\end{array}$ & $\begin{array}{l}7.754 \\
(35.98)^{* * *}\end{array}$ & $\begin{array}{l}3.710 \\
(68.34)^{* * *}\end{array}$ \\
\hline Observations & 756 & 360 & 396 \\
\hline R-squared & 0.80 & 0.88 & 0.91 \\
\hline
\end{tabular}

t statistics in parentheses.

Note: t-values are reported below each coefficient. Data sources: $X_{i j t}$ denotes total trade between countries $i$ and $j$ (millions USD - source: COMTRADE database); GDP $P_{i \text {, }}$ $G D P_{j t}$ stand for Gross Domestic Product of country $i$ and country $j$ (millions USD - source: International Monetary Fund (IMF) database); $D G D P T_{i j t}$ is the difference in Gross Domestic Product per capita between partners and is a proxy for economic distance or comparative advantage intensity (USD - source: IMF; authors' calculations);

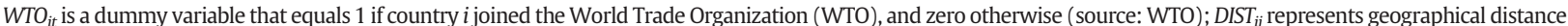
between the capitals of country $i$ and country $j$ respectively (kilometres - source: CEPI database (Centre d'Etudes Prospectives et d'Informations Internationales)); $L L K_{i j}$ is a

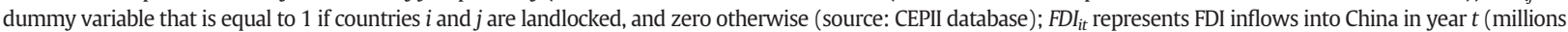
USD - source: UNCTAD database); $C R S_{t}$ is a dummy variable for the global economic crisis - equal to 1 starting from year 2007 and 0 otherwise.

* Significant at $10 \%$.

** Significant at $5 \%$.

*** Significant at $1 \%$. 
Table 3

Bilateral trade between China and EU-27.

\begin{tabular}{|c|c|c|c|}
\hline \multirow[t]{2}{*}{ Variables } & \multirow{2}{*}{$\frac{1992 \rightarrow 2012}{X_{i j t}}$} & \multirow{2}{*}{$\frac{1992 \rightarrow 2001}{X_{i j t}}$} & \multirow{2}{*}{$\frac{2002 \rightarrow 2012}{X_{i j t}}$} \\
\hline & & & \\
\hline$G D P_{i t}$ & $\begin{array}{l}1.306 \\
(15.37)^{\text {*** }}\end{array}$ & $\begin{array}{l}1.389 \\
(10.13)^{\text {*** }}\end{array}$ & $\begin{array}{l}0.871 \\
(15.27)^{* * *}\end{array}$ \\
\hline$G D P_{j t}$ & $\begin{array}{l}0.949 \\
(11.06)^{* * *}\end{array}$ & $\begin{array}{l}0.945 \\
(6.72)^{* * *}\end{array}$ & $\begin{array}{l}0.989 \\
(17.88)^{* * *}\end{array}$ \\
\hline$D_{G D P T_{i j t}}$ & $\begin{array}{l}-0.306 \\
(2.27)^{* *}\end{array}$ & $\begin{array}{l}0.791 \\
(5.54)^{* * *}\end{array}$ & $\begin{array}{l}-0.146 \\
(2.10)^{* *}\end{array}$ \\
\hline$D_{I S T} T_{i j}$ & $\begin{array}{l}-0.301 \\
(13.62)^{* * *}\end{array}$ & $\begin{array}{l}-2.017 \\
(34.16)^{* * *}\end{array}$ & $\begin{array}{l}-0.260 \\
(15.63)^{* * *}\end{array}$ \\
\hline$L L K_{i j}$ & $\begin{array}{l}-0.055 \\
(1.65)^{*}\end{array}$ & $\begin{array}{l}-0.070 \\
(1.73)^{*}\end{array}$ & $\begin{array}{l}-0.037 \\
(1.68)^{*}\end{array}$ \\
\hline$W T O_{i j t}$ & $\begin{array}{l}0.058 \\
(1.75)^{*}\end{array}$ & - & $\begin{array}{l}0.074 \\
(1.72)^{*}\end{array}$ \\
\hline$F D I_{i t}$ & $\begin{array}{l}0.212 \\
(2.36)^{* *}\end{array}$ & $\begin{array}{l}0.104 \\
(2.17)^{* *}\end{array}$ & $\begin{array}{l}0.248 \\
(7.21)^{\text {*** }}\end{array}$ \\
\hline$C R S_{t}$ & $\begin{array}{l}-0.129 \\
(2.05)^{* *}\end{array}$ & - & $\begin{array}{l}-0.142 \\
(2.39)^{* *}\end{array}$ \\
\hline Constant & $\begin{array}{l}-2.225 \\
(2.54)^{* *}\end{array}$ & $\begin{array}{l}-7.415 \\
(5.21)^{* * *}\end{array}$ & $\begin{array}{l}-2.834 \\
(4.67)^{* * *}\end{array}$ \\
\hline Observations & 1134 & 540 & 594 \\
\hline R-squared & 0.92 & 0.91 & 0.95 \\
\hline
\end{tabular}

t statistics in parentheses.

Note: t-values are reported below each coefficient. Data sources: $X_{i j t}$ denotes total trade between countries $i$ and $j$ (millions USD - source: COMTRADE database); GDP ${ }_{i t}$, $G D P_{j t}$ stand for Gross Domestic Product of country $i$ and country $j$ (millions USD - source: International Monetary Fund (IMF) database); DGDPT $T_{i j t}$ is the difference in Gross Domestic Product per capita between partners and is a proxy for economic distance or comparative advantage intensity (USD - source: IMF; authors' calculations); $W_{T O}$ is a dummy variable that equals 1 if country $i$ joined the World Trade Organization (WTO), and zero otherwise (source: WTO); DIST $_{i j}$ represents geographical distance between the capitals of country $i$ and country $j$ respectively (kilometres - source: CEPI database (Centre d'Etudes Prospectives et d'Informations Internationales)); $L L K_{i j}$ is a dummy variable that is equal to 1 if countries $i$ and $j$ are landlocked, and zero otherwise (source: CEPI database); FDlit represents FDI inflows into China in year $t$ (millions USD - source: UNCTAD database); CRSt is a dummy variable for the global economic crisis - equal to 1 starting from year 2007 and 0 otherwise.

* Significant at $10 \%$

** Significant at $5 \%$.

*** Significant at $1 \%$.

The estimated coefficients are almost always significant and their signs are consistent with the predictions of the gravity model. The country size of the exporting country and its trade partners accounts well for bilateral exports between China and the EU, and has a positive effect. Access to a sizeable market such as the EU increases trade volumes. Similarly, geographical distance and the financial crisis are again found to have a negative effect, whilst WTO membership has a positive one. The effects of the financial crisis on exports are found to be even more pronounced in this case since the EU experienced a particularly severe (debt) crisis. According to difference in GDP per capita, there is a shift towards trade in capital-intensive goods in the second period. China is a net exporter vis-àvis the EU of office machines (75), telecommunications and sound recording equipment (76), electric machinery and parts (77), and a net importer of machinery for specialized industries (72), general industrial machinery (74) and road vehicles (78). FDI inflows from the EU have a positive effect, which indicates complementarity between FDI and trade, and consequently a predominance of vertical FDI generating new trade flows through the fragmentation of the production process. ${ }^{5}$ Further, FDI inflows concern sectors for which China has a comparative advantage.

\section{Conclusions}

In this paper, we have investigated the evolution of trade flows between China and its main trade partners in Asia, North America and Europe over the period 1992-2012 using economic indicators (Lafay, 1990; Grubel and Lloyd (1975)), and panel data techniques which take into account heterogeneity and hence avoid potential biases. Our findings can be summarised as follows. China's international trade has grown steadily since the implementation of the opening-up policy, both exports and imports rising significantly. Overall, trade has increased at an average annual rate of $18.1 \%$ in the last twenty years, and the balance of trade has improved over time. China has become a big trader in world markets; although the OECD countries have been its main trading partners (the EU in particular, followed by the US and Japan), trade with the emerging economies has also increased. China relies heavily on export-led growth, and therefore a weaker world economy (for instance, following the financial crisis of 2007-8) has a negative impact on its export and GDP growth.

The most important finding of our analysis is the significant change in China's trade structure associated with the fast growth of foreign trade. In particular, there has been a shift from labour-intensive to capital- and technology-intensive exports. Most recently China has also developed a comparative advantage in capital-intensive sectors such as office machines and telecommunications and sound recording equipment vis-à-vis its main partners. Massive technology transfer through intermediate goods has contributed

\footnotetext{
5 Bloningen (2001), and Head and Ries (2001) also find a relationship between complementarity and fragmentation of the production process.
} 
significantly to the improvement in China's manufactured exports. The technological upgrading has led to highly internationalised and competitive industries (including the electrical machinery sector) being able to sell their exports to the developed economies. A convergence in the commodity compositions of exports and imports and the increase in trade in machinery parts and components indicate that intra-industry trade has become much more important in the most recent years. On the whole, there is evidence of both static and dynamic benefits of trade fostering Chinese economic growth.

\section{Appendix A}

Table A1

Trade between China and the rest of the world.

\begin{tabular}{|c|c|c|c|c|c|c|}
\hline \multirow[b]{2}{*}{ Year } & \multicolumn{3}{|c|}{ Yearly rate (\%) } & \multicolumn{3}{|c|}{ Growth vis-à-vis 1992} \\
\hline & Export & Import & Total trade & Export & Import & Total trade \\
\hline 1992 & - & - & - & - & - & - \\
\hline 1993 & 8.0 & 28.7 & 18.1 & 1.1 & 1.3 & 1.2 \\
\hline 1994 & 31.9 & 11.2 & 20.9 & 1.4 & 1.4 & 1.4 \\
\hline 1995 & 23.0 & 14.2 & 18.7 & 1.8 & 1.6 & 1.7 \\
\hline 1996 & 1.5 & 5.1 & 3.2 & 1.8 & 1.7 & 1.8 \\
\hline 1997 & 21.0 & 2.5 & 12.2 & 2.2 & 1.8 & 2.0 \\
\hline 1998 & 0.6 & -1.5 & -0.3 & 2.2 & 1.7 & 2.0 \\
\hline 1999 & 6.1 & 18.2 & 11.3 & 2.3 & 2.1 & 2.2 \\
\hline 2000 & 27.8 & 35.8 & 31.5 & 2.9 & 2.8 & 2.9 \\
\hline 2001 & 6.8 & 8.2 & 7.5 & 3.1 & 3.0 & 3.1 \\
\hline 2002 & 22.4 & 21.2 & 21.8 & 3.8 & 3.7 & 3.7 \\
\hline 2003 & 34.6 & 39.8 & 37.1 & 5.2 & 5.1 & 5.1 \\
\hline 2004 & 35.4 & 36.0 & 35.7 & 7.0 & 6.9 & 7.0 \\
\hline 2005 & 28.4 & 17.6 & 23.2 & 9.0 & 8.2 & 8.6 \\
\hline 2006 & 27.2 & 19.9 & 23.8 & 11.4 & 9.8 & 10.6 \\
\hline 2007 & 25.9 & 20.8 & 23.6 & 14.4 & 11.8 & 13.1 \\
\hline 2008 & 17.3 & 18.5 & 17.8 & 16.8 & 14.0 & 15.5 \\
\hline 2009 & -16.0 & -11.2 & -13.9 & 14.1 & 12.5 & 13.3 \\
\hline 2010 & 31.3 & 38.8 & 34.7 & 18.6 & 17.3 & 18.0 \\
\hline 2011 & 20.3 & 24.9 & 22.5 & 22.3 & 21.6 & 22.0 \\
\hline 2012 & 7.9 & 4.3 & 6.2 & 24.1 & 22.5 & 23.3 \\
\hline Average & 18.1 & 17.7 & 17.8 & - & - & - \\
\hline
\end{tabular}

Source: COMTRADE - authors' calculations.

Bold values indicate significance at average growth rate.

Table A2

China's trade shares.

\begin{tabular}{|c|c|c|c|c|c|c|c|c|c|c|c|c|}
\hline \multirow[t]{2}{*}{ Year } & \multicolumn{3}{|c|}{$\begin{array}{l}\text { Chinese trade as a \% of World } \\
\text { Trade }\end{array}$} & \multicolumn{3}{|c|}{$\begin{array}{l}\text { China's trade with the OECD as } \\
\text { a \% of total Chinese trade }\end{array}$} & \multicolumn{3}{|c|}{$\begin{array}{l}\text { China's trade with the EU as a \% } \\
\text { of total Chinese trade }\end{array}$} & \multicolumn{3}{|c|}{$\begin{array}{l}\text { China's trade with ASEAN as a \% } \\
\text { of total Chinese trade }\end{array}$} \\
\hline & Export & Import & Total & Export & Import & Total & Export & Import & Total & Export & Import & Total \\
\hline 1992 & 2.4 & 2.3 & 2.3 & 38.2 & 50.9 & 44.4 & 9.9 & 14.4 & 12.1 & 3.5 & 3.5 & 3.5 \\
\hline 1993 & 2.6 & 3.0 & 2.8 & 55.8 & 58.2 & 57.1 & 14.1 & 16.2 & 15.2 & 3.9 & 5.4 & 4.7 \\
\hline 1994 & 3.1 & 2.9 & 3.0 & 55.6 & 62.2 & 58.8 & 13.6 & 16.7 & 15.1 & 4.5 & 6.6 & 5.5 \\
\hline 1995 & 3.1 & 2.8 & 2.9 & 56.6 & 63.0 & 59.6 & 13.7 & 16.5 & 15.0 & 5.8 & 8.0 & 6.9 \\
\hline 1996 & 3.0 & 2.7 & 2.9 & 59.9 & 61.5 & 60.7 & 14.0 & 14.6 & 14.3 & 6.2 & 9.3 & 7.7 \\
\hline 1997 & 3.5 & 2.7 & 3.1 & 57.3 & 60.5 & 58.7 & 13.9 & 13.6 & 13.8 & 6.3 & 10.8 & 8.2 \\
\hline 1998 & 3.5 & 2.7 & 3.1 & 59.8 & 62.3 & 60.9 & 16.4 & 14.9 & 15.7 & 4.8 & 11.1 & 7.5 \\
\hline 1999 & 3.6 & 3.0 & 3.3 & 63.2 & 63.5 & 63.3 & 16.6 & 15.6 & 16.1 & 5.3 & 11.0 & 7.9 \\
\hline 2000 & 4.1 & 3.6 & 3.8 & 63.3 & 58.7 & 61.1 & 16.5 & 13.9 & 15.3 & 5.8 & 14.3 & 9.8 \\
\hline 2001 & 4.5 & 4.0 & 4.2 & 63.2 & 59.1 & 61.2 & 16.7 & 15.0 & 15.9 & 5.9 & 14.0 & 9.8 \\
\hline 2002 & 5.2 & 4.6 & 4.9 & 62.2 & 56.0 & 59.2 & 16.3 & 13.5 & 14.9 & 5.9 & 15.9 & 10.6 \\
\hline 2003 & 6.0 & 5.5 & 5.8 & 62.1 & 54.9 & 58.6 & 18.0 & 13.3 & 15.7 & 5.8 & 18.1 & 11.7 \\
\hline 2004 & 6.7 & 6.2 & 6.4 & 61.4 & 54.1 & 57.9 & 18.3 & 12.6 & 15.5 & 5.9 & 19.6 & 12.6 \\
\hline 2005 & 7.6 & 6.4 & 7.0 & 61.2 & 51.3 & 56.6 & 19.1 & 11.2 & 15.4 & 5.7 & 22.0 & 13.3 \\
\hline 2006 & 8.3 & 6.7 & 7.5 & 59.6 & 50.4 & 55.4 & 19.6 & 11.5 & 15.9 & 5.7 & 22.9 & 13.4 \\
\hline 2007 & 9.2 & 7.0 & 8.1 & 58.0 & 50.2 & 54.6 & 20.1 & 11.6 & 16.4 & 5.7 & 22.3 & 13.0 \\
\hline 2008 & 9.3 & 7.2 & 8.2 & 57.0 & 49.1 & 53.5 & 20.5 & 11.7 & 16.6 & 6.3 & 19.8 & 12.3 \\
\hline 2009 & 10.0 & 8.3 & 9.2 & 56.4 & 51.9 & 54.4 & 19.7 & 12.7 & 16.5 & 5.7 & 20.0 & 12.3 \\
\hline 2010 & 10.9 & 9.5 & 10.2 & 55.6 & 51.2 & 53.6 & 19.7 & 12.1 & 16.1 & 5.7 & 18.8 & 11.9 \\
\hline 2011 & 11.0 & 10.0 & 10.5 & 54.2 & 49.7 & 52.1 & 18.8 & 12.1 & 15.6 & 5.8 & 17.5 & 11.4 \\
\hline 2012 & 12.2 & 10.5 & 11.3 & 51.5 & 47.6 & 49.7 & 16.3 & 11.7 & 14.1 & 5.8 & 18.3 & 11.7 \\
\hline
\end{tabular}

Source: COMTRADE - authors' calculations. 
Table A3

The top trading partners (\% of total Chinese trade).

\begin{tabular}{|c|c|c|c|c|c|c|c|c|c|c|c|c|c|c|c|}
\hline \multirow[t]{3}{*}{ Year } & \multirow{2}{*}{\multicolumn{3}{|c|}{$\begin{array}{l}\text { Total trade with the } 18 \\
\text { main partners }\end{array}$}} & \multicolumn{12}{|c|}{ Of which: } \\
\hline & & & & \multicolumn{3}{|l|}{ US } & \multicolumn{3}{|l|}{ Japan } & \multicolumn{3}{|c|}{ Hong-Kong } & \multicolumn{3}{|c|}{ Germany } \\
\hline & Export & Import & Total & Export & Import & Total & Export & Import & Total & Export & Import & Total & Export & Import & Total \\
\hline 1992 & 87.0 & 84.3 & 85.7 & 10.1 & 11.0 & 10.6 & 13.7 & 16.9 & 15.3 & 44.2 & 25.4 & 35.0 & 2.9 & 5.0 & 3.9 \\
\hline 1993 & 83.6 & 83.5 & 83.5 & 18.5 & 10.3 & 14.1 & 17.2 & 22.4 & 20.0 & 24.0 & 10.0 & 16.6 & 4.3 & 5.8 & 5.1 \\
\hline 1994 & 84.6 & 83.6 & 84.1 & 17.7 & 12.0 & 14.9 & 17.8 & 22.8 & 20.2 & 26.7 & 8.2 & 17.7 & 3.9 & 6.2 & 5.0 \\
\hline 1995 & 83.6 & 82.4 & 83.0 & 16.6 & 12.2 & 14.5 & 19.1 & 22.0 & 20.5 & 24.2 & 6.5 & 15.9 & 3.8 & 6.1 & 4.9 \\
\hline 1996 & 84.0 & 81.9 & 83.0 & 17.7 & 11.6 & 14.8 & 20.4 & 21.0 & 20.7 & 21.8 & 5.6 & 14.1 & 3.9 & 5.3 & 4.5 \\
\hline 1997 & 83.2 & 80.7 & 82.1 & 17.9 & 11.5 & 15.1 & 17.4 & 20.4 & 18.7 & 24.0 & 4.9 & 15.6 & 3.6 & 4.3 & 3.9 \\
\hline 1998 & 81.6 & 81.6 & 81.6 & 20.7 & 12.0 & 16.9 & 16.1 & 20.2 & 17.9 & 21.1 & 4.7 & 14.0 & 4.0 & 5.0 & 4.4 \\
\hline 1999 & 81.5 & 80.9 & 81.2 & 21.5 & 11.8 & 17.1 & 16.6 & 20.4 & 18.3 & 18.9 & 4.2 & 12.1 & 4.0 & 5.0 & 4.5 \\
\hline 2000 & 80.5 & 75.5 & 78.2 & 20.9 & 9.9 & 15.7 & 16.7 & 18.4 & 17.5 & 17.9 & 4.2 & 11.4 & 3.7 & 4.6 & 4.2 \\
\hline 2001 & 79.9 & 76.0 & 78.0 & 20.4 & 10.8 & 15.8 & 16.9 & 17.6 & 17.2 & 17.5 & 3.9 & 11.0 & 3.7 & 5.7 & 4.6 \\
\hline 2002 & 79.7 & 76.0 & 77.9 & 21.5 & 9.2 & 15.7 & 14.9 & 18.1 & 16.4 & 18.0 & 3.6 & 11.1 & 3.5 & 5.6 & 4.5 \\
\hline 2003 & 78.6 & 73.4 & 76.1 & 21.1 & 8.2 & 14.9 & 13.6 & 18.0 & 15.7 & 17.4 & 2.7 & 10.3 & 4.0 & 5.9 & 4.9 \\
\hline 2004 & 77.8 & 70.8 & 74.4 & 21.1 & 8.0 & 14.7 & 12.4 & 16.8 & 14.5 & 17.0 & 2.1 & 9.8 & 4.0 & 5.4 & 4.7 \\
\hline 2005 & 76.6 & 68.3 & 72.7 & 21.4 & 7.4 & 14.9 & 11.0 & 15.2 & 13.0 & 16.3 & 1.9 & 9.6 & 4.3 & 4.7 & 4.4 \\
\hline 2006 & 74.0 & 66.5 & 70.7 & 21.0 & 7.5 & 14.9 & 9.5 & 14.6 & 11.8 & 16.0 & 1.4 & 9.4 & 4.2 & 4.8 & 4.4 \\
\hline 2007 & 71.3 & 64.5 & 68.3 & 19.1 & 7.3 & 13.9 & 8.4 & 14.0 & 10.8 & 15.1 & 1.3 & 9.1 & 4.0 & 4.7 & 4.3 \\
\hline 2008 & 68.2 & 61.6 & 65.3 & 17.7 & 7.2 & 13.0 & 8.1 & 13.3 & 10.4 & 13.3 & 1.1 & 7.9 & 4.1 & 4.9 & 4.5 \\
\hline 2009 & 68.3 & 63.1 & 65.9 & 18.4 & 7.7 & 13.5 & 8.1 & 13.0 & 10.4 & 13.8 & 0.9 & 7.9 & 4.2 & 5.5 & 4.8 \\
\hline 2010 & 67.8 & 61.9 & 65.0 & 18.0 & 7.4 & 13.0 & 7.7 & 12.7 & 10.0 & 13.8 & 0.9 & 7.8 & 4.3 & 5.3 & 4.8 \\
\hline 2011 & 66.6 & 59.0 & 63.0 & 17.1 & 7.1 & 12.3 & 7.8 & 11.2 & 9.4 & 14.1 & 0.9 & 7.8 & 4.0 & 5.3 & 4.6 \\
\hline 2012 & 66.8 & 57.3 & 62.4 & 17.2 & 7.4 & 12.6 & 7.4 & 9.8 & 8.5 & 15.8 & 1.0 & 8.8 & 3.4 & 5.1 & 4.2 \\
\hline
\end{tabular}

Source: COMTRADE - authors' calculations.

Table A4

Lafay index: China and its main partners.

\begin{tabular}{|c|c|c|c|c|c|c|c|c|c|c|}
\hline \multirow[b]{2}{*}{ SITC-2 } & \multirow{2}{*}{$\frac{\text { Lafay China }}{\text { Text }}$} & \multicolumn{3}{|l|}{ US } & \multicolumn{3}{|l|}{ Japan } & \multicolumn{3}{|c|}{ Germany } \\
\hline & & 1992 & 2002 & 2012 & 1992 & 2002 & 2012 & 1992 & 2002 & 2012 \\
\hline 62 & Rubber manufactures, n.e.s. & 0.05 & 0.20 & 0.34 & -0.15 & -0.13 & -0.11 & 0.05 & -0.09 & -0.01 \\
\hline 63 & Wood and cork manufactures & 0.23 & 0.32 & 0.29 & 0.45 & 0.62 & 0.39 & 0.49 & 0.04 & 0.23 \\
\hline 64 & Paper, paperboard and articles thereof & -1.08 & -0.51 & 0.02 & -0.64 & -0.25 & 0.23 & -0.47 & -0.46 & 0.07 \\
\hline 65 & Textile yarn, fabrics, made up articles, etc. & 2.38 & 0.70 & 0.90 & -0.61 & -0.38 & 0.66 & 3.96 & 1.39 & 1.30 \\
\hline 66 & Non-metallic mineral manufactures, n.e.s. & 0.68 & 0.39 & 0.28 & 0.13 & 0.25 & 0.02 & 0.50 & 0.32 & 0.63 \\
\hline 67 & Iron and steel & -0.37 & 0.13 & 0.15 & -5.54 & -3.18 & -1.44 & -2.60 & -1.49 & -0.32 \\
\hline 68 & Non-ferrous metals & -0.64 & -0.18 & -0.34 & -0.28 & -0.46 & -1.05 & -0.33 & -0.48 & -0.59 \\
\hline 69 & Manufactures of metals, n.e.s. & 1.57 & 1.61 & 1.15 & 0.12 & 0.46 & 0.52 & 1.75 & 1.44 & 0.94 \\
\hline 71 & Power generating machinery and equipment & -1.47 & -0.53 & -0.63 & -1.48 & -0.40 & -0.75 & -2.30 & -2.52 & -1.02 \\
\hline 72 & Machinery for specialized industries & -2.92 & -1.35 & -0.62 & -7.57 & -4.21 & -2.41 & -10.79 & -7.74 & -3.24 \\
\hline 73 & Metal working machinery & -0.58 & -0.57 & -0.23 & -0.75 & -1.17 & -1.72 & -2.21 & -2.18 & -1.93 \\
\hline 74 & General industrial machinery n.e.s. & -0.59 & -1.23 & 0.06 & -3.16 & -1.58 & -0.41 & -3.28 & -3.79 & -3.88 \\
\hline 75 & Office machines and adp machines & -0.93 & 1.98 & 6.76 & -1.12 & 2.30 & 3.18 & 0.40 & 4.28 & 8.00 \\
\hline 76 & Telecommunications and sound recording equipm & -0.76 & 2.57 & 4.67 & -2.56 & 1.99 & 3.63 & -0.17 & 7.04 & 2.72 \\
\hline 77 & Electric machinery, n.e.s. and parts & -0.85 & -2.08 & -0.43 & -2.86 & -8.58 & -5.27 & -1.58 & 0.31 & 1.17 \\
\hline 78 & Road vehicles & -0.96 & 0.85 & -1.06 & -4.20 & -1.55 & -3.05 & -8.26 & -5.03 & -12.15 \\
\hline 79 & Other transport equipment & -4.98 & -3.45 & -2.20 & -0.46 & 0.03 & -0.24 & -0.61 & 0.32 & -0.54 \\
\hline 81 & Prefabr. buildings; sanitary, lighting, fixtrs etc. & 0.16 & 0.71 & 0.57 & -0.05 & 0.10 & 0.39 & 0.02 & 0.62 & 0.97 \\
\hline 82 & Furniture and parts thereof & 1.16 & 1.81 & 1.75 & 0.25 & 0.92 & 1.18 & 0.66 & 0.33 & 1.38 \\
\hline 83 & Travel goods, handbags and sim. containers & 0.78 & 0.59 & 0.71 & 0.23 & 0.67 & 0.58 & 0.61 & 0.79 & 0.76 \\
\hline 84 & Articles of apparel and clothing accessories & 9.65 & 3.05 & 3.27 & 11.79 & 11.30 & 7.26 & 10.78 & 4.75 & 5.65 \\
\hline 85 & Footwear & 8.53 & 2.84 & 1.44 & 0.77 & 1.03 & 0.88 & 2.65 & 0.61 & 1.28 \\
\hline 87 & Instruments and apparates n.e.s. & -2.23 & -1.99 & -1.45 & -0.88 & -1.36 & -2.20 & -1.26 & -1.63 & -1.80 \\
\hline 88 & Photographic equipment, optical goods etc. & 0.20 & 0.09 & -0.08 & -0.72 & -0.59 & -0.82 & 0.02 & 0.62 & 0.21 \\
\hline 89 & Miscellaneous manufactured articles, n.e.s. & 4.35 & 5.10 & 2.81 & 0.83 & 1.56 & 1.94 & 3.56 & 2.91 & 2.82 \\
\hline
\end{tabular}


Table A5

Grubel-Lloyd index: China and its main partners.

\begin{tabular}{|c|c|c|c|c|c|c|c|c|c|c|}
\hline \multirow[b]{2}{*}{ SITC-2 } & \multirow{2}{*}{$\frac{\text { Grubel-Lloyd China }}{\text { Text }}$} & \multicolumn{3}{|l|}{ US } & \multicolumn{3}{|l|}{ Japan } & \multicolumn{3}{|c|}{ Germany } \\
\hline & & 1992 & 2002 & 2012 & 1992 & 2002 & 2012 & 1992 & 2002 & 2012 \\
\hline 0 & Live animals & 0.05 & 0.54 & 0.39 & 0.02 & 0.43 & 0.68 & 1.00 & 0.58 & 0.05 \\
\hline 3 & Fish and fish preparations & 0.26 & 0.23 & 0.55 & 0.05 & 0.10 & 0.08 & 0.04 & 0.10 & 0.06 \\
\hline 6 & Sugars, sugar preparations and honey & 0.08 & 0.37 & 0.20 & 0.04 & 0.36 & 0.06 & 0.02 & 0.43 & 0.80 \\
\hline 8 & Feeding stuff for animals & 0.03 & 0.32 & 0.65 & 0.35 & 0.05 & 0.03 & 0.26 & 0.26 & 0.09 \\
\hline 9 & Miscellaneous edible products and preparations & 0.64 & 0.93 & 0.93 & 0.40 & 0.17 & 0.32 & 0.59 & 0.21 & 0.82 \\
\hline 22 & Oil seeds, oleaginous fruits & 0.05 & 0.00 & 0.01 & 0.00 & 0.01 & 0.01 & 0.00 & 0.93 & 0.00 \\
\hline 27 & Crude fertilizers and crude minerals & 0.22 & 0.46 & 0.41 & 0.04 & 0.07 & 0.24 & 0.07 & 0.60 & 0.40 \\
\hline 28 & Metalliferous ores and metal scrap & 0.00 & 0.01 & 0.01 & 0.12 & 0.45 & 0.01 & 0.04 & 0.01 & 0.00 \\
\hline 29 & Crude animal, vegetable materials n.e.s. & 0.64 & 0.70 & 0.65 & 0.12 & 0.30 & 0.15 & 0.05 & 0.14 & 0.17 \\
\hline 33 & Petroleum and products & 0.13 & 0.55 & 0.43 & 0.11 & 0.32 & 0.27 & 0.05 & 0.79 & 0.34 \\
\hline 41 & Animal oils and fats & 0.05 & 0.07 & 0.20 & 0.44 & 0.06 & 0.01 & 0.00 & 0.00 & 0.28 \\
\hline 43 & Processed animal or vegetable oils, etc. & 0.47 & 0.75 & 0.81 & 0.71 & 0.28 & 0.63 & 0.35 & 0.93 & 0.50 \\
\hline 51 & Organic chemicals & 0.37 & 0.69 & 0.63 & 0.53 & 0.20 & 0.47 & 0.63 & 0.69 & 0.73 \\
\hline 52 & Inorganic chemicals & 0.36 & 0.60 & 0.69 & 0.20 & 0.55 & 0.44 & 0.53 & 0.69 & 0.35 \\
\hline 53 & Dyeing, tanning and colouring material & 0.26 & 0.32 & 0.64 & 0.24 & 0.50 & 0.42 & 0.09 & 0.43 & 0.42 \\
\hline 54 & Medicinal and pharmaceutical products & 0.40 & 0.22 & 0.55 & 0.64 & 0.73 & 0.45 & 0.27 & 0.24 & 0.48 \\
\hline 55 & Perfume, cleaning, preparations etc. & 0.41 & 0.41 & 0.56 & 0.08 & 0.41 & 0.79 & 0.30 & 0.30 & 0.43 \\
\hline 56 & Fertilizers, manufactured & 0.00 & 0.00 & 0.54 & 0.47 & 0.01 & 0.05 & 0.00 & 0.00 & 0.00 \\
\hline 57 & Plastics in primary forms & 0.05 & 0.17 & 0.27 & 0.04 & 0.04 & 0.21 & 0.28 & 0.08 & 0.14 \\
\hline 58 & Plastics in non-primary forms & 0.12 & 0.57 & 0.69 & 0.08 & 0.08 & 0.27 & 0.16 & 0.18 & 0.44 \\
\hline 59 & Chemical materials and products, n.e.s. & 0.17 & 0.30 & 0.40 & 0.46 & 0.52 & 0.43 & 0.29 & 0.16 & 0.31 \\
\hline 61 & Leather, dressed fur, etc. & 0.12 & 0.25 & 0.09 & 0.27 & 0.27 & 0.13 & 0.20 & 0.30 & 0.13 \\
\hline 62 & Rubber manufactures, n.e.s. & 0.65 & 0.19 & 0.19 & 0.18 & 0.72 & 0.71 & 0.85 & 0.31 & 0.42 \\
\hline 63 & Wood and cork manufactures & 0.17 & 0.13 & 0.03 & 0.10 & 0.21 & 0.02 & 0.04 & 0.11 & 0.24 \\
\hline 64 & Paper, paperboard and articles thereof & 0.07 & 0.32 & 0.25 & 0.20 & 0.18 & 0.71 & 0.17 & 0.10 & 0.26 \\
\hline 65 & Textile yarn, fabrics, made up articles, etc. & 0.13 & 0.17 & 0.13 & 0.46 & 0.53 & 0.39 & 0.19 & 0.22 & 0.29 \\
\hline 66 & Non-metallic mineral manufactures, n.e.s. & 0.23 & 0.18 & 0.32 & 0.21 & 0.60 & 0.42 & 0.23 & 0.31 & 0.48 \\
\hline 67 & Iron and steel & 0.34 & 0.25 & 0.33 & 0.08 & 0.25 & 0.26 & 0.04 & 0.07 & 0.50 \\
\hline 68 & Non-ferrous metals & 0.07 & 0.57 & 0.48 & 0.27 & 0.58 & 0.38 & 0.04 & 0.25 & 0.32 \\
\hline 69 & Manufactures of metals, n.e.s. & 0.25 & 0.17 & 0.20 & 0.86 & 0.81 & 0.59 & 0.36 & 0.56 & 0.68 \\
\hline 71 & Power generating machinery and equipment & 0.23 & 0.63 & 0.54 & 0.26 & 0.62 & 0.58 & 0.22 & 0.13 & 0.49 \\
\hline 72 & Machinery for specialized industries & 0.09 & 0.43 & 0.62 & 0.02 & 0.11 & 0.29 & 0.02 & 0.06 & 0.19 \\
\hline 73 & Metal working machinery & 0.36 & 0.43 & 0.76 & 0.05 & 0.13 & 0.17 & 0.16 & 0.09 & 0.14 \\
\hline 74 & General industrial machinery n.e.s. & 0.53 & 0.76 & 0.54 & 0.09 & 0.45 & 0.64 & 0.16 & 0.29 & 0.40 \\
\hline 75 & Office machines and adp machines & 0.55 & 0.38 & 0.05 & 0.20 & 0.69 & 0.37 & 0.48 & 0.46 & 0.06 \\
\hline 76 & Telecommunications and sound recording equipm & 0.27 & 0.31 & 0.05 & 0.28 & 0.49 & 0.51 & 0.19 & 0.34 & 0.28 \\
\hline 77 & Electric machinery, n.e.s. and parts & 0.42 & 0.36 & 0.35 & 0.27 & 0.41 & 0.43 & 0.22 & 0.46 & 0.73 \\
\hline 78 & Road vehicles & 0.18 & 0.10 & 0.09 & 0.03 & 0.10 & 0.26 & 0.01 & 0.06 & 0.09 \\
\hline 79 & Other transport equipment & 0.30 & 0.09 & 0.16 & 0.14 & 0.80 & 0.25 & 0.03 & 0.14 & 0.07 \\
\hline 81 & Prefabr. buildings; sanitary, lighting, fixtrs etc. & 0.12 & 0.03 & 0.03 & 0.30 & 0.39 & 0.10 & 0.76 & 0.14 & 0.11 \\
\hline 82 & Furniture and parts thereof & 0.03 & 0.02 & 0.03 & 0.23 & 0.23 & 0.15 & 0.23 & 0.82 & 0.30 \\
\hline 83 & Travel goods, handbags and sim. containers & 0.00 & 0.00 & 0.00 & 0.06 & 0.02 & 0.01 & 0.00 & 0.01 & 0.02 \\
\hline 84 & Articles of apparel and clothing accessories & 0.00 & 0.00 & 0.00 & 0.05 & 0.08 & 0.01 & 0.01 & 0.01 & 0.00 \\
\hline 85 & Footwear & 0.01 & 0.02 & 0.01 & 0.06 & 0.70 & 0.01 & 0.00 & 0.03 & 0.01 \\
\hline 87 & Instruments and apparates, n.e.s. & 0.20 & 0.50 & 0.59 & 0.17 & 0.18 & 0.48 & 0.14 & 0.36 & 0.33 \\
\hline 88 & Photographic equipment, optical goods etc. & 0.46 & 0.47 & 0.40 & 0.40 & 0.65 & 0.48 & 0.56 & 0.45 & 0.58 \\
\hline 89 & Miscellaneous manufactured articles, n.e.s. & 0.13 & 0.11 & 0.16 & 0.44 & 0.59 & 0.46 & 0.09 & 0.22 & 0.35 \\
\hline 93 & Special transactions and commodities not classified & 0.85 & 0.08 & 0.01 & 0.90 & 0.01 & 0.08 & 0.81 & 0.21 & 0.75 \\
\hline 96 & Coin (not gold coin or legal) & 0.89 & 0.96 & 0.24 & 0.00 & 0.00 & 0.14 & 0.00 & 0.00 & 0.01 \\
\hline
\end{tabular}

Source: COMTRADE - authors' calculations. 


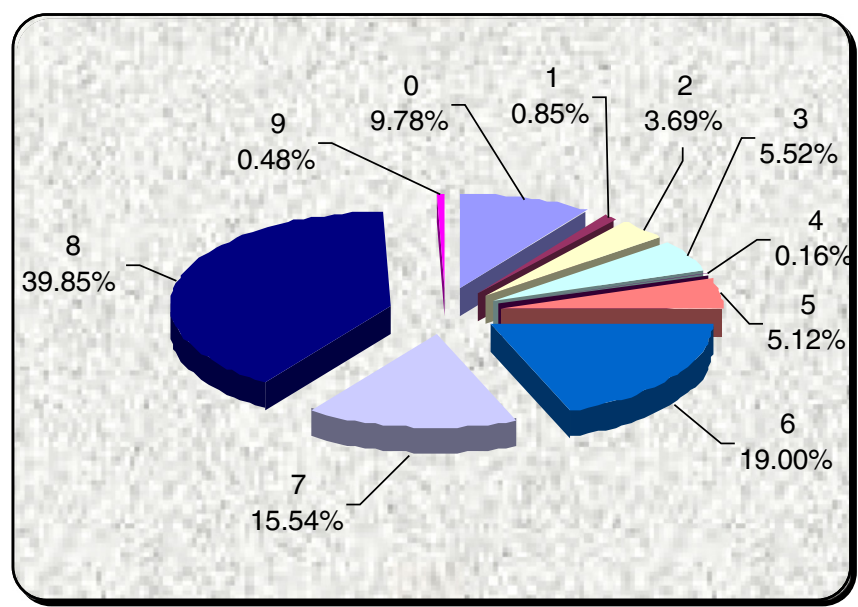

Source:Comtrade

Fig. A1. Chinese exports to the rest of the world (1992).

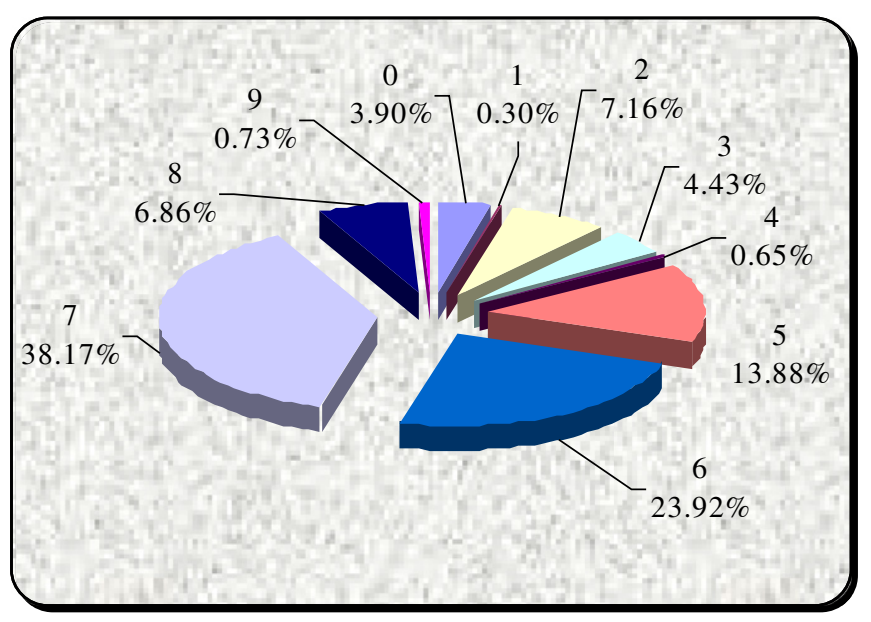

Source:Comtrade

Fig. A2. Chinese imports from the rest of the world (1992).

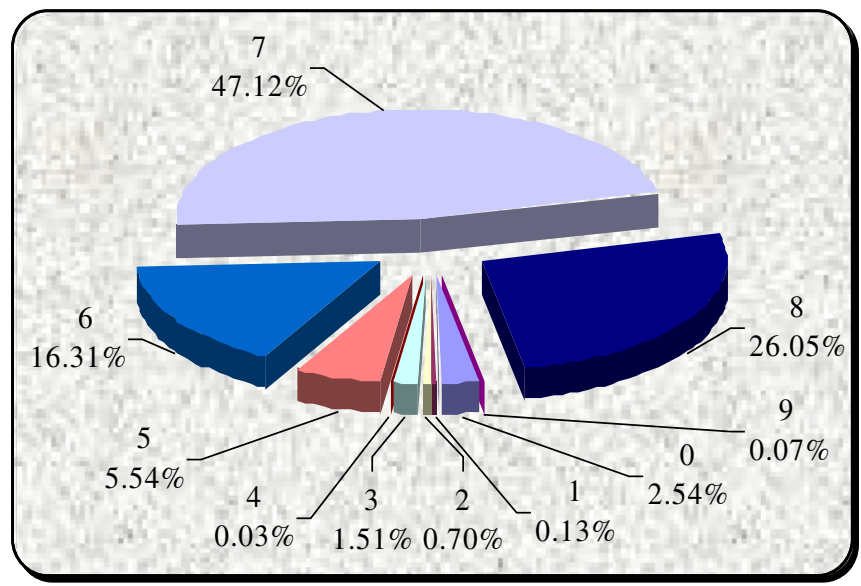

Source:Comtrade

Fig. A3. Chinese exports to the rest of the world (2012). 


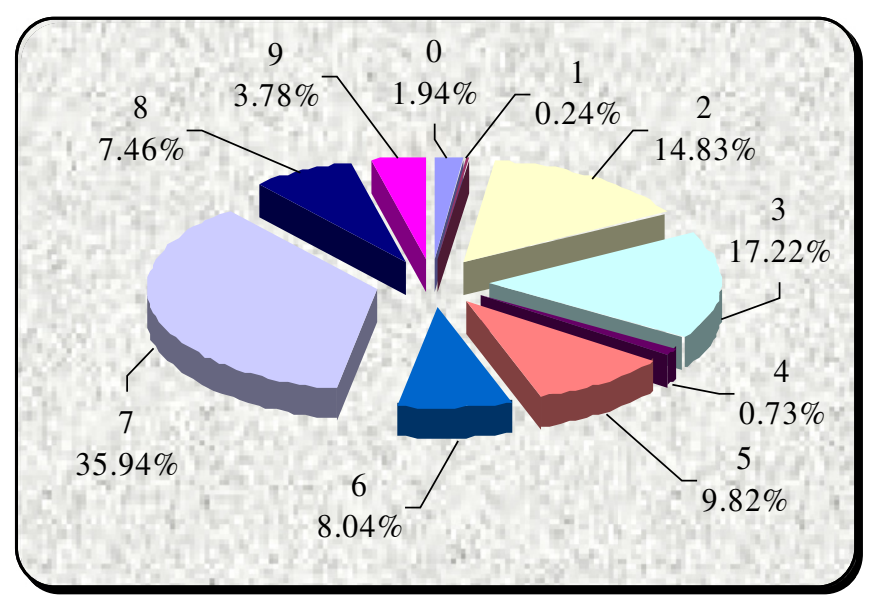

Source:Comtrade

Fig. A4. Chinese imports from the rest of the world (2012).

Table A6

List of SITC -1 sectors

\begin{tabular}{llll}
\hline Code & Sector & Code & Sector \\
\hline 0 & Food and live animals & 5 & Chemicals and related products, n.e.s. \\
1 & Beverages and tobacco & 6 & Basic manufactures \\
2 & Crude materials, inedible, except fuels & 7 & Machinery, transport equipment \\
3 & Mineral fuels etc. & 8 & Miscellaneous manufactured articles \\
4 & Animal and vegetable oils and fats & 9 & Goods not classified elsewhere \\
\hline
\end{tabular}

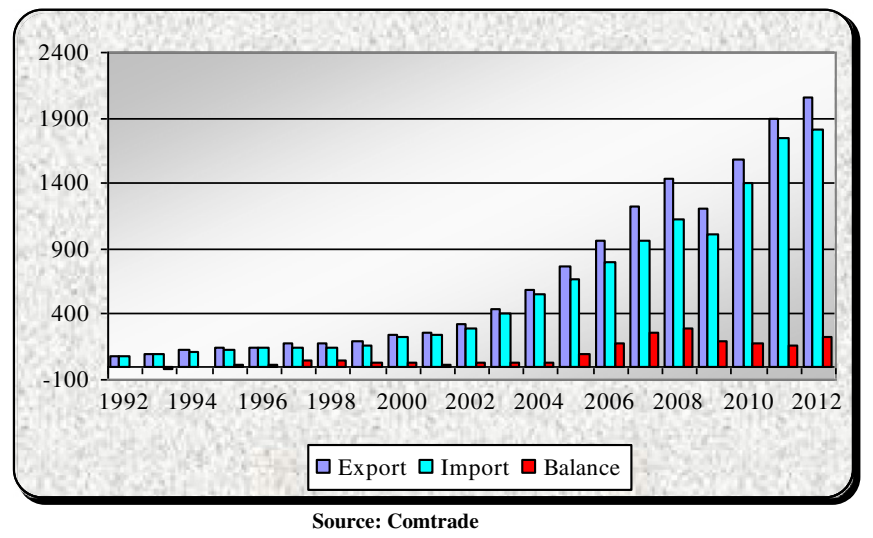

Fig. A5. Trade between China and the rest of the world (billions $\$$ ). 


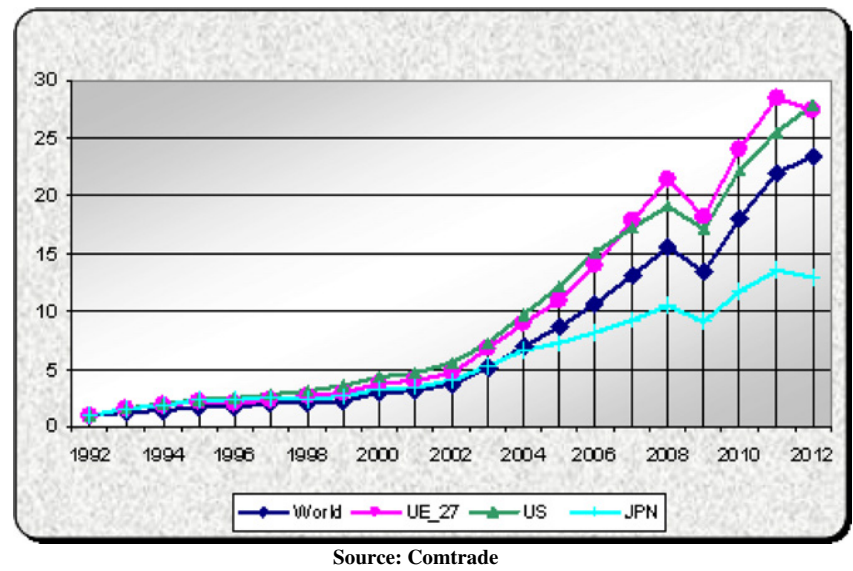

Fig. A6. Trade growth since 1992 .

\section{References}

Adams, F. G., Gangnes, G., \& Shachmurove, Y. (2006). Why is China so competitive? Measuring and explaining China's competitiveness. The World Economy, 29(2), 95-122.

Anderson, J. E. (1979). A theoretical foundation for the gravity equation. American Economic Review, 69(1), 106-116.

Anderson, J. E., \& Van Wincoop, E. (2003). Gravity with gravitas: A solution to the border effect puzzle. American Economic Review, 93(1), $170-192$.

Ando, M. (2006). Fragmentation and vertical intra-industry trade in East Asia. North American Journal of Economics and Finance, 17, $257-281$.

Arora, V., \& Vamvakidis, A. (2004). How much do trading partners matter for economic growth? IMF Working Paper, 04/26, Washington: International Monetary Fund. Bahmani-Oskooee, M., \& Ratha, A. (2010). S-Curve dynamics of trade between U.S. and China. China Economic Review, 21, $212-223$.

Baldwin, R. (1994). Towards an integrated Europe. London: CEPR.

Bergstrand, J. H. (1985). The gravity equation in international trade: Some microeconomic foundations and empirical evidence. Review of Economics and Statistics, 67(3), 474-481.

Bergstrand, J. H. (1989). The generalized gravity equation, monopolistic competition, and the factor-proportions theory in international trade. Review of Economics and Statistics, 71(1), 143-153.

Bloningen, B. A. (2001). In search of substitution between foreign production and exports. Journal of International Economics, 53(1), 81-104.

Carrere, C. (2006). Revisiting the effects of regional trading agreements on trade flows with proper specification of gravity model. European Economic Review, 50, 223-247.

Cross, K. H. (2004). China's WTO accession: Economic, legal, and political implications. Boston College International and Comparative Law Review, 27(2), 319-370.

Egger, P., \& Pfaffermayr, M. (2003). The proper panel econometric specification of the gravity equation: A three-way model with bilateral interaction effects. Empirical Economics, 28, 571-580.

Eichengreen, B., \& Irwin, D. A. (1995). Trade blocs, currency blocs and the reorientation of world trade in the 1930s. Journal of International Economics, 38(1-2), 1-24. Evenett, S. J., \& Keller, W. (2002). On theories explaining the success of the gravity equation. Journal of Political Economy, 110(2), 281-316.

Frankel, J. (1997). Regional trading blocs in the world economic system. Institute for International Economics Washington.

Greeven, M. J. (2004). The evolution of high-tech in China after 1978: Towards technological entrepreneurship. ERIM Report Series Research in Management.

Grubel, H. G., \& Lloyd, P. J. (1975). Intra-industry trade: The theory and measurement of international trade in differential products. London: Macmillan.

Head, K., \& Ries, J. (2001). Overseas investment and firm exports. Review of International Economics, 9, 108-122.

Helpman, E. (1987). Imperfect competition and international trade: Evidence from fourteen industrial countries. Journal of the Japanese and International Economies, 1 , $62-81$.

Helpman, E., \& Krugman, P. R. (1985). Market Structure and Foreign Trade: Increasing Returns, Imperfect Competition, and the International Economy. Cambridge/Mass. MIT Press.

Hummels, D., \& Levinsohn, J. (1995). Monopolistic competition and international trade: Reconsidering the evidence. Quarterly Journal of Economics, 110, 798-836.

Lafay, G. (1990). La mesure des avantages comparatifs révélés. Économie Prospective Internationale, 41.

Lee, H. -H., Park, D., \& Wang, J. (2013). Different types of firms, different types of products, and their dynamics: An anatomy of China's imports. China Economic Review, $25,62-77$.

Linnemann, H. (1966). An econometric Study of International Trade Flows. Amsterdam: North Holland.

Marelli, E., \& Signorelli, M. (2011). China and India: Openness, trade and effects on economic growth. The European Journal of Comparative Economics, 8(1), $129-154$.

Matyas, L. (1997). Proper econometric specification of the gravity model. The World Economy, 20(3), 363-368.

Péridy, N. (2005). Towards a new trade policy between the USA and Middle-East Countries: Estimating trade resistance and export potential. World Economy, 28(4), 491-518.

Plumper, T., \& Troeger, V. E. (2007). Efficient estimation of time-invariant and rarely changing variables in finite sample panel analyses with unit fixed effects. Political Analysis, 15(2), 124-139.

Pöyhönen, P. A. (1963). Tentative model for the volume of trade between countries. Welwirtschftliches Archiv, 90(1), 93-99.

Tinbergen, J. (1962). Shaping the world economy: Suggestions for an international economic policy. New York: The Twentieth Century Fund.

Wei, Y., \& Liu, X. (2006). Productivity spillovers from R\&D, exports and FDI in China's manufacturing sector. Journal of International Business Studies, $37,544-557$.

Xing, W., \& Whalley, J. (2014). The Golden Tax Project, value-added tax statistics, and the analysis of internal trade in China. China Economic Review, $30,448-458$.

Yang, S., \& Martinez-Zarzozo, I. (2014). A panel data analysis of trade creation and trade diversion effects: The case of ASEAN-China free trade area. China Economic Review, 29, 138-151. 